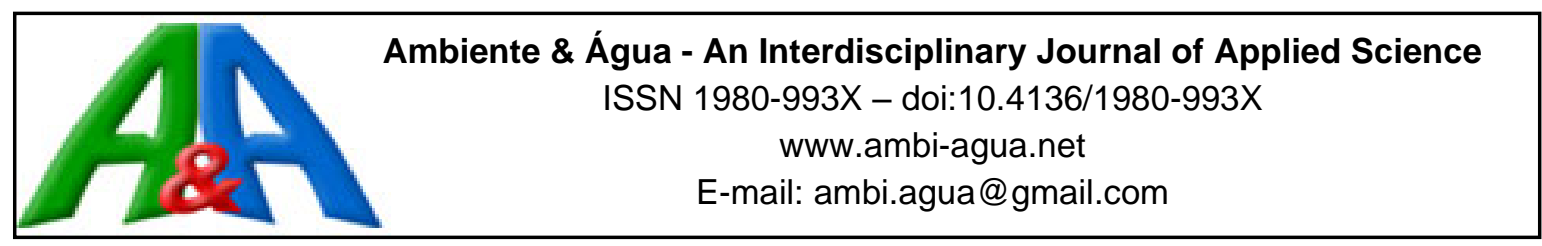

\title{
Monitoring of fluoride in the public water supply using electrometric or colorimetric analyses
}

\author{
ARTICLES doi:10.4136/ambi-agua.2603
}

Received: 25 Jun. 2020; Accepted: 05 Oct. 2020

\author{
Caio Luiz Lins-Candeiro' ${ }^{(D)}$; Karen Katlein Dolenkei ${ }^{1}$ (D); \\ Luiz Renato Paranhos ${ }^{2}$; Douglas Queiroz Santos ${ }^{3}$; \\ Jaime Aparecido Cury ${ }^{4}$; Juliana Pereira da Silva Faquim ${ }^{3 *}$ \\ ${ }^{1}$ Faculdade de Odontologia. Universidade Federal de Uberlândia (UFU), Avenida Pará, \\ n 1720, CEP: 38405320, Uberlândia, MG, Brazil. \\ E-mail: caiocandeiro@yahoo.com.br, karendolenkei@hotmail.com \\ ${ }^{2}$ Departamento de Odontologia Preventiva e Social. Faculdade de Odontologia. \\ Universidade Federal de Uberlândia (UFU), Avenida Pará, n 1720, CEP: 38405320, Uberlândia, MG, Brazil. \\ E-mail: paranhos.lrp@gmail.com \\ ${ }^{3}$ Escola Técnica de Saúde. Universidade Federal de Uberlândia (UFU), Avenida Amazonas, Bloco 4K, \\ CEP: 38400-902, Uberlândia, MG, Brazil. E-mail: douglas@ufu.br \\ ${ }^{4}$ Escola de Odontologia de Piracicaba. Departamento de Biociências. Universidade Estadual de Campinas \\ (UNICAMP), Avenida Limeira, n 910, CEP: 13414-903, Piracicaba, SP, Brazil. E-mail: jcury@unicamp.br \\ *Corresponding author. E-mail: julianafaquim@ufu.br
}

\begin{abstract}
The surveillance of the concentration of fluoride in the public water supply aims to ensure the balance between the benefits (carie prevention) and risk (dental fluorosis) of water fluoridation programs. The aim of this study was to check the accuracy of two analytical methods for monitoring the concentration of fluoride in the public water supply of a Brazilian city. The STROBE checklist was used to aid the conduction of this study and report the results. It was an analytical, observational, and prospective study using the water supply of Uberlândia, MG, Brazil. We collected 126 water samples at 21 sites for six consecutive months and analyzed them using the fluoride ion selective electrode (F-ISE) method and colorimetry with SPADNS. The statistical analysis was performed descriptively and then the ANOVA and Student $t$-test for paired samples were applied. The results showed that the F-ISE method had a lower coefficient of variation $(12.3 \%)$ than the SPADNS method $(57.4 \%)$. There was no significant variation of the fluoride concentration in the water through the supply network evaluated either by F-ISE as SPADNS. We concluded that the electrometric method should be the first choice for use by laboratories that monitor fluoride concentration in the public supply water.
\end{abstract}

Keywords: fluoridation, sanitary surveillance, water supply.

\section{Monitoramento de flúor no abastecimento público de água por meio de análises eletrométricas e colorimétricas}

\section{RESUMO}

A vigilância da concentração de flúor na água de abastecimento público visa garantir o equilíbrio entre o benefício (prevenção de cárie) e risco (fluorose dental) dos programas da 
fluoretação de água. O objetivo deste estudo foi verificar a precisão de dois métodos analíticos no monitoramento da concentração de flúor na água de abastecimento público de uma cidade brasileira. O checklist STROBE foi utilizado para auxiliar na condução desta pesquisa e relatar os resultados. Tratou-se de um estudo observacional analítico, de caráter prospectivo utilizando a água de abastecimento de Uberlândia, MG. Foram coletadas 126 amostras de água, em 21 pontos, durante seis meses seguidos e analisadas por meio do método com eletrodo íon seletivo (F-SIE) e por colorimetria com o SPADNS. A análise estatística foi realizada de maneira descritiva, em seguida, empregou-se o teste ANOVA e o teste $t$ de Student para amostras pareadas. Os resultados mostraram que o método eletrométrico mostrou menor coeficiente de variação $(12,3 \%)$ quando comparado o método colorimétrico $(57,4 \%)$. Não foi observada variação significativa da concentração de fluoreto na água avaliada pelo F-ISE e SPADNS. Conclui-se que o método eletrométrico deve ser de primeira escolha para ser utilizado por laboratórios que monitoram a concentração de flúor nas águas de abastecimento público.

Palavras-chave: abastecimento de água, fluoretação, vigilância sanitária.

\section{INTRODUCTION}

Fluorine is considered the main reason for decreasing cases of carie diseases worldwide (Maia et al., 2003; Cho et al., 2014; Jordan et al., 2017). Over four decades, fluorine has been used for controlling dental caries, resulting in a significant improvement in the oral health of the population (Frazão et al., 2018). Fluorine presents low cost (Leivas et al., 2010), high effectiveness (Frazão et al., 2018), and especially an extensive population coverage, regardless of age and social and economic conditions (Burt, 2002; Petersen and Lennon, 2004).

Providing a more effective delivery of the benefit to the population requires that the fluoride concentration remains at an "optimal level" (Amaral et al., 2007). Hence, controlling fluorine concentration in the public water supply is essential, as well as the operational control performed by companies in water treatment plants (Frazão et al., 2018).

Regardless of the local temperature, there is great variability in fluorine concentrations in the water (Buzalaf et al., 2013; Paredes et al., 2014; Bergamo et al., 2015; Piorunneck et al., 2017; Uchida et al., 2018). Determining fluoride in the water requires the use of the electrometric method with specific ion electrode by the direct method, as well as the colorimetric method by the SPADNS method or the Alizarine visual colorimetric method (APHA et al., 2012). The Ion Chromatography method is also used (Dovidauskas et al., 2017) but sporadically.

This study compared two assessment methods of fluoride concentration in the public water supply and determined the better one to use as an oral health surveillance tool. The following hypotheses were tested: (1) The electrometric method presents a lower coefficient of variation than the colorimetric method; (2) There are differences in fluorine ion concentrations between the population receiving water in regions distant from the site of fluoride addition and the population living close to the Water Treatment Plants.

\section{MATERIALS AND METHODS}

\subsection{Ethical research criteria and protocol}

This was an observational study that did not involve human beings and animals, therefore its submission to the Research Ethics Committee was not required. The STROBE checklist Strengthening the Reporting of Observational Studies in Epidemiology (Von Elm et al., 2008) was used to aid the research and the reporting of results. 


\subsection{Type and characterization of the study location}

It was an analytical, observational, and prospective study performed in the city of Uberlândia, Minas Gerais - southeast region of Brazil. The city of Uberlândia, according to the Brazilian Institute of Geography and Statistics (IBGE, 2020) for 2016, has an estimate of 669,672 inhabitants - the second largest city of the state of Minas Gerais. According to the report of the Trata Brasil Institute (Instituto Trata Brasil, 2016), Uberlândia has the third best sanitation service in Brazil and it is considered a reference. The city also has $100 \%$ water coverage and $99 \%$ sewage collection coverage. One hundred percent of the sewage collected is treated.

In 1967, the city government created the Municipal Department of Water and Sewage (DMAE), establishing the construction of the first Water Treatment Plant (WTP). Currently, Uberlândia has two working plants (Sucupira WTP and Bom Jardim WTP) and one more under construction (Capim Branco WTP). Figure 1 shows the coverage area of each WTP. The north and east sections are supplied by the Bom Jardim WTP and the central, south, and west sections are supplied by the Sucupira WTP. It is worth noting that a small area of the west section is supplied by both WTPs.

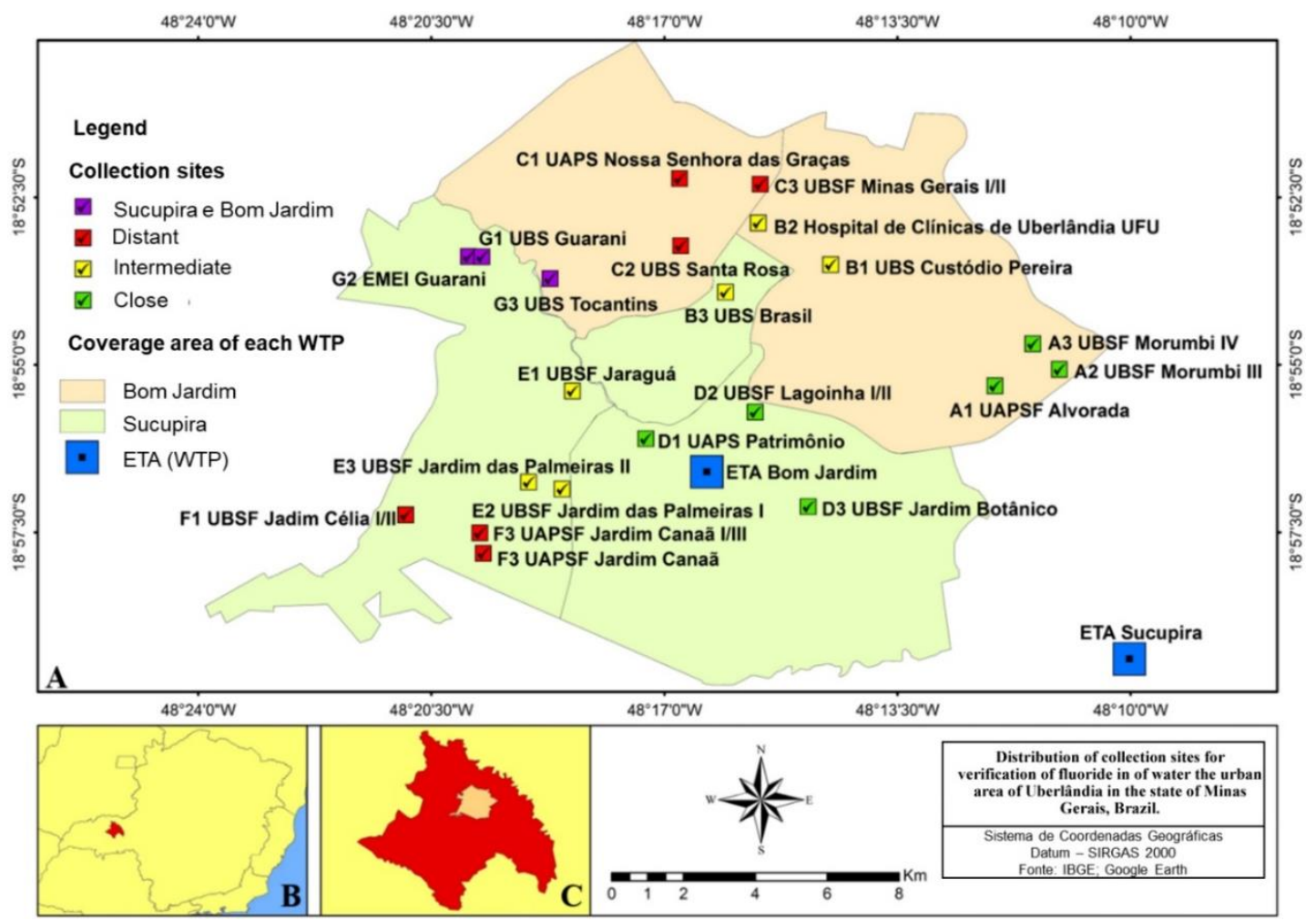

Figure 1. A) Distribution of collection sites in the urban area of Uberlândia. B) Location of the city of Uberlândia in the state of Minas Gerais, Brazil. C) Delimitation of the urban area in the territory extension of the city (Lins-Candeiro, 2018).

To define the collection sites, we analyzed the representativity and space coverage of each WTP, following the branch supply network. Hence, it was required to understand the water distribution network of the city, locate the number of treatment plants, and identify the existence of alternative collective solutions and the coverage of these systems.

Three main sites were defined, with one close to the WTP, an intermediate, and one distant from the WTP. For each of these three main sites, two additional close sites were established (Figure 2). Thus, there were a total of nine sites for each WTP and three additional collection sites for the region supplied by both WTPs. The locations prioritized for such collections were health units and public schools. 


\section{DEFINITION OF THE NUMBER OF WATER COLLECTION SITES}
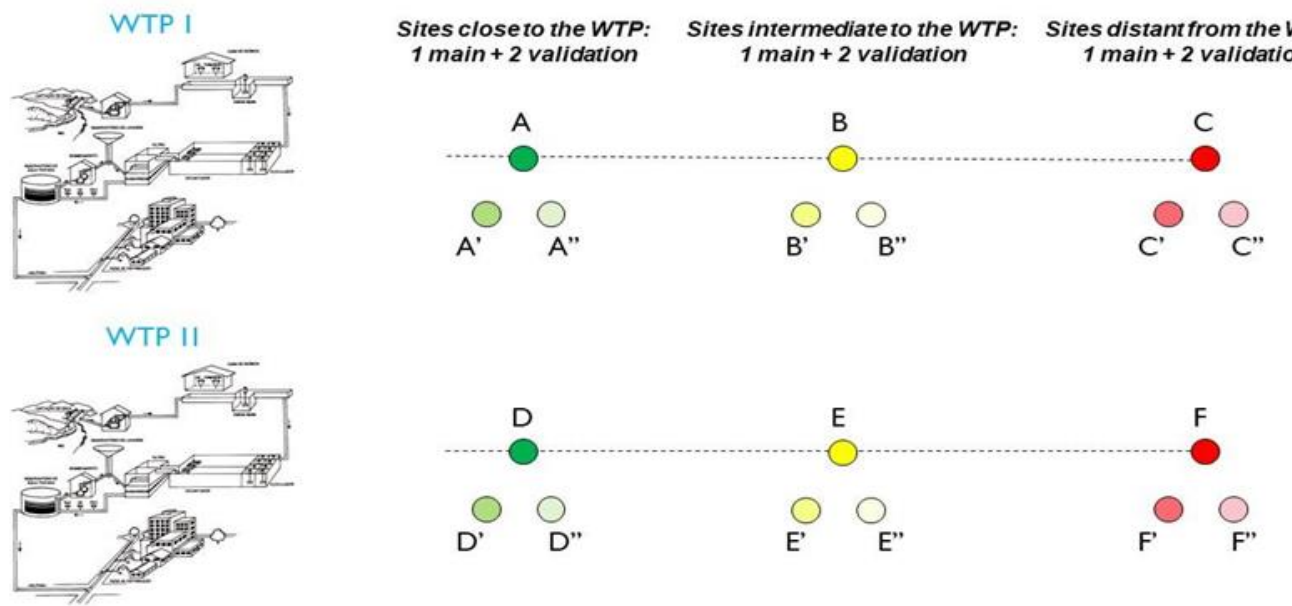

Figure 2. Adapted and summarized scheme of the sampling method for the analysis of fluoride in the city of Uberlândia, MG, Brazil. To the collection site A1 (main site), two more validation sites (A2 and A3) are added close to the WTP. Sites B1, B2, and B3 correspond to the collection sites at an intermediate distance from the WTP. Sites C1, C2, and $\mathrm{C} 3$ refer to the collections distant from the WTP. Sites D, E, F, and G followed the same dynamic of sites A, B, and C (CECOL, 2011).

The city has a region where the population is supplied by both WTPs (Bom Jardim and Sucupira). Therefore, the study chose to draw three additional collection sites in this region to assess the water supplying the population. The samples received the letter $G$ for identification in the results tables.

The collections were performed once a month for six months (CECOL, 2014). One hundred and twenty-six water samples were collected in plastic recipients with a natural pressure cap and capacity of $20 \mathrm{~mL}$, which were identified previously with a permanent marker. The water samples collected were analyzed in the laboratory of the Technical Course in Environmental Control and Environment of the Technical School of Health of the Federal University of Uberlândia.

\subsection{Description of methods}

The electrometric and colorimetric methods were performed to quantify the fluorine ion content in the samples collected. The electrometric method is based on the direct measurement of free fluorine ions and it uses the fluoride ion selective electrode (F-ISE) as the main tool. This electrode has a fluoride crystal membrane from which a potential is established by fluoride solutions of different concentrations, determining the calibration of the electrode. Quantification occurs when the electrode is immersed in the solution (sample and reagent) and the crystal contacts the sample solution on one surface and the internal reference solution on the other surface. When removing the electrode, it is important to rinse it with distilled water and dry it in-between readings. The minimum reading range in the quantification of the fluorides of this method is approximately $0.02 \mathrm{ppm}$ of $\mathrm{F}^{-}$and the maximum is $19000 \mathrm{ppm}$ of fluorine (APHA et al., 2012).

The principle of the colorimetric method is the reading method based on the reaction between fluorine and a zirconium-dye lake. According to the amount of fluorine, the liquid becomes lighter (more fluorine) or darker (less fluorine), and the filter photometer provides the concentration value. For this method, the minimum reading value in the quantification of fluorides is $0.05 \mathrm{ppm} \mathrm{F}^{-}$and the maximum value is $2.0 \mathrm{ppm}$ of fluorine (APHA et al., 2012). 


\subsection{Data collection}

The samples were analyzed with a selective ion electrode (Analion ${ }^{\mathrm{TM}}$ ) coupled to a potentiometer (Adwa ${ }^{\mathrm{TM}}$ model AD 1000) for the electrometric method and with a SPADNS solution analysis kit for the colorimetric method by Nanocolor REF 918142. The reagent used in the samples for the electrometric analysis was the TISAB II (Total Ionic Strength Adjustment Buffer II), pH 5.0, in the standards of 0.125 - 0.500 - 1.000 ppm F'.

The electrode used was calibrated before the analysis with standards between 0.125 and $1.0 \mathrm{ppm} \mathrm{F}^{-}$. In the interval between assessments, the electrode was washed with distilled and deionized water and dried with an absorbent paper towel. For the colorimetric method, the reagent was added to the samples and after five minutes it was subjected to the spectrophotometer to analyze the concentration of $\mathrm{F}^{-}$. The results were expressed in $\mathrm{mg} \mathrm{F}^{-} / \mathrm{L}$ $(\mathrm{ppm} \mathrm{F})^{-}$.

\subsection{Data analysis}

Initially, a descriptive statistical analysis was performed to characterize the samples. Next, ANOVA was used to identify significant differences in water fluoridation within the months of the study and the different collection sites. Student t-test for paired samples was also performed to compare the results obtained with the electrometric and colorimetric methods (Larson and Farber, 2016). The significance level was set at 5\% ( $<<0.05)$. All analyses were performed with the help of the IBM SPSS Statistics software, Version 20.0, considering a 95\% confidence interval to obtain the estimates.

\section{RESULTS}

The data reported between November 2015 and April $2016(n=126)$ revealed the mean monthly values of the fluoride concentration in the public water supply. The differences between the monthly means, calculated with repeated measures ANOVA, showed a statistically significant difference in water fluoridation between the months collected $(p<0.001)$ for each method monitored. The Table 1 shows the monthly means assessed.

Table 1. Mean of fluoride contents in the public water supply in Uberlândia (MG), Brazil, for all collection sites.

\begin{tabular}{ccccc}
\hline & \multicolumn{2}{c}{ Electrometric Method } & \multicolumn{2}{c}{ Colorimetric Method } \\
\cline { 2 - 5 } Period & $\begin{array}{c}\text { Fluorine Content } \\
(\mathbf{p p m F})\end{array}$ & $\begin{array}{c}\text { Standard deviation } \\
(\mathbf{p p m})\end{array}$ & $\begin{array}{c}\text { Fluorine Content } \\
(\mathbf{p p m F})\end{array}$ & $\begin{array}{c}\text { Standard deviation } \\
(\mathbf{p p m F})\end{array}$ \\
\hline November/2015 & 0.62 & 0.07 & 0.72 & 0.10 \\
December/2015 & 0.60 & 0.04 & 0.33 & 0.11 \\
January/2016 & 0.55 & 0.08 & 0.38 & 0.17 \\
February/2016 & 0.60 & 0.03 & 0.73 & 0.09 \\
March/2016 & 0.56 & 0.04 & 1.29 & 0.52 \\
April/2016 & 0.53 & 0.08 & 0.65 & 0.08 \\
\hline General & $\mathbf{0 . 5 7}$ & $\mathbf{0 . 0 7}$ & $\mathbf{0 . 6 8}$ & $\mathbf{0 . 3 9}$ \\
\hline
\end{tabular}

Note: Differences between the monthly means (ANOVA test for repeated measures, $p<0.001$ ); Differences between two methods (Student $\mathrm{t}$-test for paired samples, $\mathrm{p}=0.002$ ).

Using the electrometric method evidenced a general mean of $0.57 \mathrm{ppm} \mathrm{F}^{-}$, which was considered moderate for carie prevention. The month of November showed the highest fluorine concentration $(0.62 \pm 0.07)$, while the lowest was seen in April $(0.53 \pm 0.08)$. The colorimetric method presented a general mean of $0.68 \mathrm{ppm} \mathrm{F}^{-}$. The month of March showed the highest fluoride concentration $(1.29 \pm 0.52)$ and the lowest was seen in December $(0.33 \pm 0.11)$. The 
comparison between these two methods, performed by the Student t-test for paired samples, showed statistically significant differences $(p=0.002)$.

The results showed that the mean value of fluoride in the water is lower when assessed by the electrometric method $(0.57 \pm 0.07)$ than the colorimetric method $(0.68 \pm 0.39)$. However, when analyzing the fluorine concentration of the water samples according to the collection sites (Table 2), the colorimetric method showed a higher coefficient of variance (57.4\%) than the electrometric method (12.3\%).

Table 2. Fluorine concentration of the water samples according to the collection site in Uberlândia (MG), Brazil, by collection site.

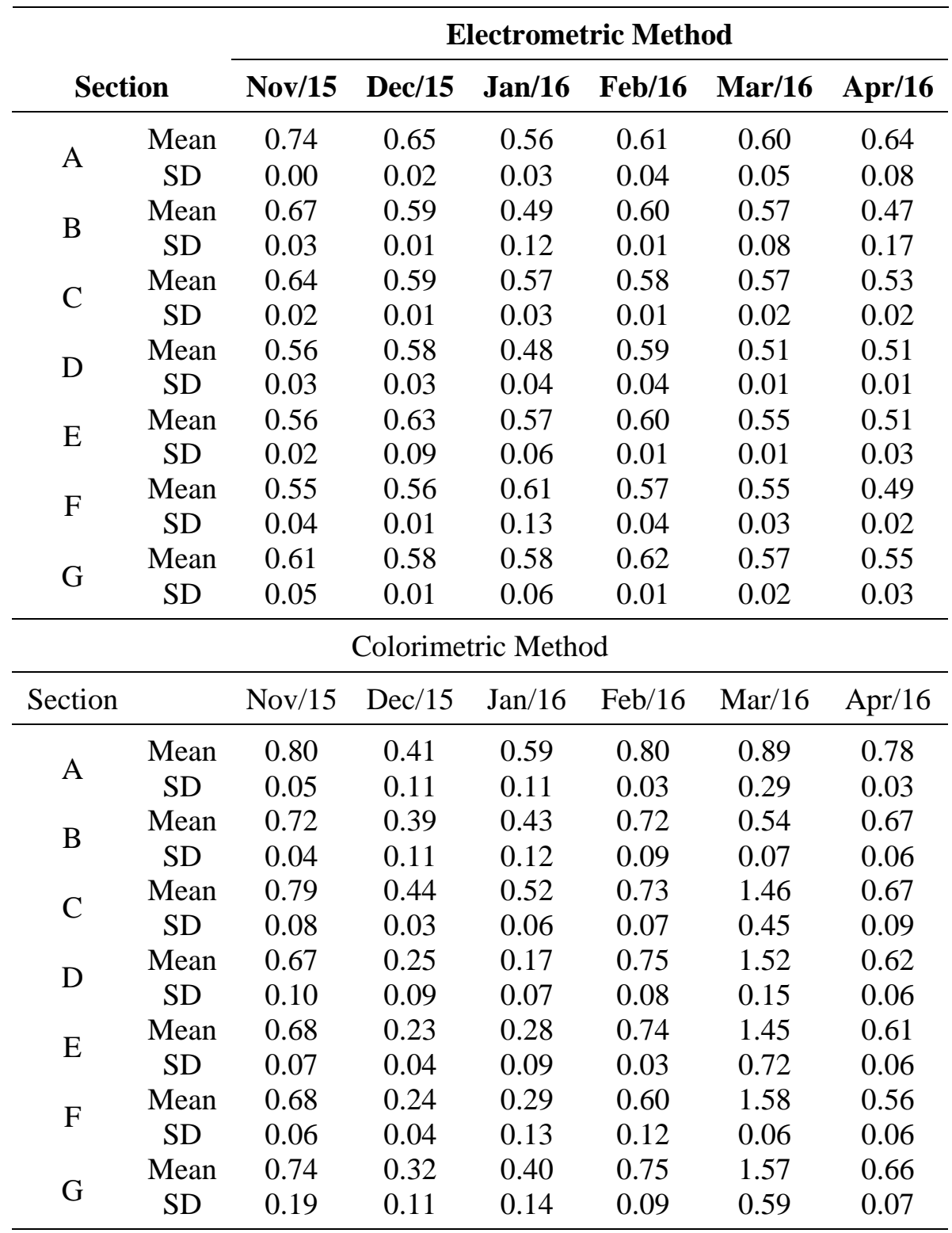

Note: Descriptive statistics; $\mathrm{SD}=$ standard deviation.

Lastly, the mean fluoride values were compared using ANOVA according to the distance of water collection sites relative to the WTP in Uberlândia (close, intermediate, and distant), aiming to investigate some variation of concentration to be attributed to the water distribution network (Table 3). However, there were no statistically significant differences regarding the distance of collection sites relative to the WTP when comparing the results obtained with the electrometric $(p=0.815)$ and colorimetric $(p=0.155)$ methods. 
Table 3. Mean fluorine concentration of the water samples according to the distance of water collection sites relative to the WTP in Uberlândia (MG), Brazil.

\begin{tabular}{|c|c|c|c|c|c|c|c|}
\hline \multirow{2}{*}{ Collection sites } & & \multicolumn{6}{|c|}{ Electrometric Method } \\
\hline & & Nov/15 & Dec/15 & Jan/16 & Feb/16 & Mar/16 & Apr/16 \\
\hline \multirow{2}{*}{ Close } & Mean & 0.65 & 0.61 & 0.52 & 0.60 & 0.56 & 0.57 \\
\hline & $\mathrm{SD}$ & 0.10 & 0.05 & 0.05 & 0.03 & 0.06 & 0.09 \\
\hline \multirow{2}{*}{ Intermediate } & Mean & 0.62 & 0.61 & 0.53 & 0.60 & 0.56 & 0.49 \\
\hline & SD & 0.06 & 0.06 & 0.10 & 0.01 & 0.05 & 0.11 \\
\hline \multirow{2}{*}{ Distant } & Mean & 0.59 & 0.58 & 0.59 & 0.58 & 0.56 & 0.51 \\
\hline & $\mathrm{SD}$ & 0.06 & 0.02 & 0.08 & 0.03 & 0.02 & 0.03 \\
\hline \multirow{2}{*}{ Sucupira and Bom Jardim } & Mean & 0.61 & 0.58 & 0.58 & 0.62 & 0.57 & 0.55 \\
\hline & $\mathrm{SD}$ & 0.05 & 0.01 & 0.06 & 0.01 & 0.02 & 0.03 \\
\hline \multicolumn{8}{|c|}{ Colorimetric Method } \\
\hline \multicolumn{2}{|l|}{ Collection sites } & Nov/15 & Dec/15 & $\mathrm{Jan} / 16$ & Feb/16 & Mar/16 & Apr/16 \\
\hline \multirow{2}{*}{ Close } & Mean & 0.74 & 0.33 & 0.38 & 0.78 & 1.20 & 0.70 \\
\hline & $\mathrm{SD}$ & 0.10 & 0.12 & 0.25 & 0.06 & 0.40 & 0.10 \\
\hline \multirow{2}{*}{ Intermediate } & Mean & 0.70 & 0.31 & 0.36 & 0.73 & 0.99 & 0.64 \\
\hline & SD & 0.06 & 0.12 & 0.12 & 0.06 & 0.68 & 0.06 \\
\hline \multirow{2}{*}{ Distant } & Mean & 0.73 & 0.34 & 0.41 & 0.66 & 1.52 & 0.62 \\
\hline & SD & 0.08 & 0.11 & 0.15 & 0.11 & 0.29 & 0.09 \\
\hline \multirow{2}{*}{ Sucupira and Bom Jardim } & Mean & 0.74 & 0.32 & 0.40 & 0.75 & 1.57 & 0.66 \\
\hline & $\mathrm{SD}$ & 0.19 & 0.11 & 0.14 & 0.09 & 0.59 & 0.07 \\
\hline
\end{tabular}

Note: ANOVA for electrometric $(\mathrm{p}=0.815)$ and colorimetric $(\mathrm{p}=0.155)$ methods.

\section{DISCUSSION}

This study compared the electrometric and colorimetric methods to verify the fluorine ion concentration in the public water supply. The results showed that the electrometric method had a lower variation than the colorimetric method. Moreover, none of the methods studied showed a reduction in the fluoride concentration from the WTP up to the farthest collection sites, which suggests there are no hidden wells through the network because ANOVA did not show statistical differences.

The results of the present study indicate that the electrometric method has a higher coefficient of variance than the colorimetric method, which means that the electrometric method presents higher precision. Similar results were observed in other studies (Ferreira and Benedet, 1999; Motter et al., 2011). The electrometric method has higher precision than the colorimetric method (alizarine and spectrophotometric) in the presence of fluoride at $0.6 \mathrm{ppm}$ (Ferreira and Benedet, 1999). The colorimetric method presented, on average, double the fluoride concentration when compared with the electrometric method, which may be explained by the interference it suffers from chemical substances such as chloride $\left(\mathrm{Cl}^{-}\right)$, hexametaphosphate $\left(\left[\mathrm{NaPO}_{2}\right]_{6}\right)$, phosphate $\left(\mathrm{PO}_{4}{ }^{3-}\right)$, aluminum $\left(\mathrm{Al}^{3+}\right)$, iron $(\mathrm{Fe})$, or sulfate $\left(\mathrm{SO}_{4}{ }^{2-}\right)$. It is worth noting that, despite the fact that these substances also interfere with the electrometric method, the effect is smaller (APHA et al., 2012). There are also limitations for the use of the colorimetric method, considering that samples cannot be cloudy or colored, should be distilled before the analysis (APHA et al., 2012; Prasad et al., 2018), and cannot contain free residual chlorine (Dovidauskas et al., 2016).

While these limitations are presented for the colorimetric method, the electrometric method does not require any type of sample preparation (APHA et al., 2012), which makes it easy to perform, considering it is exempt from a previous analysis phase (Moimaz et al., 2015) and consequently has a lower cost (Bratovcic et al., 2009; Dovidauskas et al., 2016; Balkunde et al., 2016). Thus, this study suggests that the electrometric method be used as the main method 
for surveilling the quality of water fluoridation (Ramires and Buzalaf, 2007; Do Carmo et al., 2010; Leivas et al., 2010; Moimaz et al., 2012; De Brito et al., 2016; Uchida et al., 2018).

The results presented in studies (Zimmer et al., 2003; Leivas et al., 2010; De Brito et al., 2016) did not assess the difference of $\mathrm{F}^{-}$among sites close, intermediate, and distant from the WTP. The analyses of fluorine contents in this study at the sites from the WTP did not show a loss of fluorine through the water distribution network, suggesting there is no chemical reaction of fluorine.

The results of this study also show that, despite not being included in the central objective of the investigation, it is worth noting that the mean fluoride level in the city studied was lower than that recommended for the local characteristics. The mean temperature of the collection months was $25.75^{\circ} \mathrm{C}$, therefore suggesting a water fluorine content between 0.65 and 0.94 , which interval is considered a maximum benefit and low risk. However, the mean observed using the electrometric method was $0.57 \mathrm{ppm} \mathrm{F}^{-}$, a value considered a moderate benefit and low risk of fluorosis, as well as another study (Ramires and Buzalaf, 2007) that presented mean concentrations of $\mathrm{F}^{-}$. For the colorimetric method, the mean content of $\mathrm{F}^{-}$was $0.68 \mathrm{ppm} \mathrm{F}$, which value provides maximum benefit and low risk of fluorosis.

In this sense, it stands out that the city studied does not present an effective Oral Health Surveillance policy, not even for water fluoridation, which is restricted to operational control. Several studies recommend Oral Health Surveillance (Narvai, 2000; Zimmer et al., 2003; Lima et al., 2004; Moimaz et al., 2015; Frazão et al., 2018) for an external control besides operational control, thus providing the achievement of reliable results regarding fluoride levels (Ramires and Buzalaf, 2007; CECOL, 2011; Frazão et al., 2018), enhancing this public health strategy, promoting anti-carie coverage, and preventing fluorosis. Fluoridation control by institutions not involved directly in its operation is an essential condition to preserve the quality of the process and for information credibility (Lima et al., 2004; Olivati et al., 2011).

The low number of studies found comparing methods is an important limitation. However, the present study is original, indicates the most effective method, and it may easily be used to maintain a better standard of drinking water, allowing the implementation of public policies to maintain the quality of the health surveillance service.

The establishment of local Oral Health Surveillance policies is an essential measure to ensure that the fluorine concentration in the water supply is sufficient to provide the high effectiveness of fluorine ion and low risk of fluorosis. The investment in this type of policy should be directed to the use of the electrometric method in both the fluoride addition site and the sites distant from the WTP. Moreover, Oral Health Surveillance should include an understanding of the epidemiological dynamic of dental caries in the cities.

\section{CONCLUSION}

The electrometric and colorimetric methods for fluoride monitoring in the public water supply, when compared, present statistically different results and precision, and the electrometric method is the more precise. The distance between the WTP and the sampling sites does not affect statistically the fluoride content in the public water supply and there is a statistically significant difference in fluoride concentration regarding the sampling month.

\section{REFERENCES}

AMARAL, R. C.; WADA, R. S.; SOUSA, L. M. R. Concentração de fluoretos nas águas de abastecimento público relacionada à temperatura em Piracicaba - SP. Revista da Faculdade de Odontologia, v. 12, n. 3, p. 24-28, 2007. https://doi.org/10.5335/rfo.v12i3.1064 
APHA; AWWA; WEF. Standard Methods for the examination of water and wastewater. 22nd ed. Washington, 2012. $1496 \mathrm{p}$.

BALKUNDE, P.; KRISHNAN, S.; RAJKUMAR, S.; HALERY, N.; LEVIN, S. Monitoring of fluoride in water samples using a smartphone. The Science of the Total Environment. v. 551-552, p. 101-107, 2016. https://doi.org/10.1016/j.scitotenv.2016.01.156

BERGAMO, E. T. P.; BARBANA, M.; TERADA, R. S. S.; CURY, J. A.; FUJIMAKI, M. Fluoride concentrations in the water of Maringá, Brazil, considering the benefit/risk balance of caries and fluorosis. Brazilian Oral Research, v. 29, n. 1, p. 1-6, 2015. https://doi.org/10.1590/1807-3107bor-2015.vol29.0047

BRATOVCIC, A.; ODOBASIC, A.; CATIC, S. The advantages of the use of ion-selective potentiometry in relation to UV/VIS spectroscopy. Agriculturae Conspectus Scientificus, v. 74, n. 3, p. 139-142, 2009.

BURT, B. A. Fluoridation and social equity. Journal of Public Health Dentistry, v. 62, n. 4, p. 195-200, 2002. https://doi.org/10.1111/j.1752-7325.2002.tb03445.x

BUZALAF, M. A. R.; MORAES, C. M.; OLYMPIO, K. P. K; PESSAN, P.; GRIZZO, L. T.; SILVA, T. L.; MAGALHÃES, A. C.; OLIVEIRA, R. C.; GROISMAN, S.; RAMIRES, I. Seven years of external control of fluoride levels in the public water supply in Bauru, São Paulo, Brazil. Journal of Applied Oral Science, v. 21, n. 1, p. 92-98, 2013. https://doi.org/10.1590/1678-7757201302196

CECOL. Consenso técnico sobre classificação de águas de abastecimento público segundo o teor de flúor. Brasília, 2011.

CECOL. Guia de Amostragem para Vigilância da Concentração do Fluoreto na Água de Abastecimento Público. 2014. Available at: http://www.cecol.fsp.usp.br/dcms/uploads/arquivos/1411739637_ManualGuia_Amostragem-v.1.0.pdf. Access on 31 May 2020.

CHO, H. J.; JIN, B. H.; PARK, D. Y.; JUNG, S. H.; LEE, H. S.; PAIK, D. I.; BAE, K. H. Systemic effect of water fluoridation on dental caries prevalence. Community Dentistry

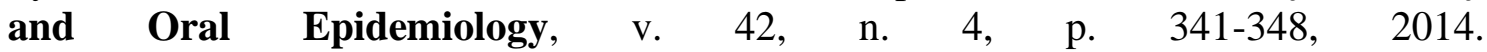
https://doi.org/10.1111/cdoe.12091

DE BRITO, C. S.; GARBIN, R. R.; MUSSI, A.; RIGO, L. Vigilância da concentração de flúor nas águas de abastecimento público na cidade de Passo Fundo - RS. Cadernos Saúde Coletiva, v. 24, n. 4, p. 452-459, 2016. https://doi.org/10.1590/1414-462x201600040240

DO CARMO, C. D. S.; ALES, C. M. C.; CAVALCANTE, P. R.; RIBEIRO, C. C. C. Avaliação da fluoretação da água do sistema de abastecimento público na Ilha de São Luís, Maranhão, Brasil. Ciência \& Saúde Coletiva, v. 15, supl. 1, p. 1835-1840, 2010. https://doi.org/10.1590/S1413-81232010000700096

DOVIDAUSKAS, S.; OKADA, I. A.; IHA, H.; CAVALLINI, A. G.; OKADA, M. M.; BRIGANTI, R. C. Avaliação da qualidade da fluoretação de águas de abastecimento público em 88 municípios da região Nordeste do estado de São Paulo (Brasil). Vigilância Sanitária em Debate, v. 5, n. 3, p. 14- 23, 2017. https://doi.org/10.22239/2317-269x.00926

DOVIDAUSKAS, S.; OKADA, I. A.; OKADA, M. M.; BRIGANTI, R. C.; DE OLIVEIRA, C. C. Determinação de fluoreto em baixas concentrações: validação de método com eletrodo íon seletivo para análise da água utilizada na preparação de soluções de diálise. Revista do Instituto Adolfo Lutz, v. 74, n. 4. p. 347-360, 2016. 
FERREIRA, R.; BENEDET, H.D. Comparação de métodos para determinação de flúor. Boletim do Centro de Pesquisa e Processamento de Alimentos, v. 17, n. 1, p. 53-58, 1999.

FRAZÃO, P.; ELY, H. C.; NORO, L. R. A.; PINHEIRO, H. H. C.; CURY, J. A. O modelo de vigilância da água e a divulgação de indicadores de concentração de fluoreto. Saúde em Debate, v. 42, n. 116, p. 274-286, 2018. https://doi.org/10.1590/0103-1104201811622

FRAZÃO, P.; PERES, M. A. P.; CURY, J. A. Drinking water quality and fluoride concentration. Revista de Saúde Pública, v. 45, n. 5, p. 964-73, 2011. https://doi.org/10.1590/S0034-89102011005000046

IBGE. Censo demográfico do município de Uberlândia, Minas Gerais, Brasil. Available at http://cidades.ibge.gov.br/xtras/perfil.php?codmun=317020. Access on 26 May 2020.

INSTITUTO TRATA BRASIL. Relatório Ranking do Saneamento. Instituto Trata Brasil 2016. Available at http://portaldoamazonas.com/wp-content/uploads/2016/04/relatoriocompleto.pdf. Access on 26 May 2020.

JORDAN, R. A.; SCHULTE, A.; BOCKELBRINK, A. C.; NAUMOVA, S. P. E.; WÄRN, L. G.; ZIMMER, S. Caries-Preventive Effect of Salt Fluoridation in Preschool Children in The Gambia: A Prospective, Controlled, Interventional Study. Caries Research. v. 51, n. 6, p. 596- 604, 2017. https://doi.org/10.1159/000479892

LARSON, R.; FARBER, B. Estatística Aplicada. 6. ed. São Paulo: Pearson Prentice Hall, 2016.

LEIVAS, L. L.; TOVO, M. F.; ARDENGHI, T. M.; FELDENS, C. A.; KRAMER, P. F.; FARACO JUNIOR, I. M. Heterocontrole da fluoretação das águas de abastecimento público do Município de Canoas/RS. Stomatos, v. 16, n. 30, p. 11-20, 2010.

LIMA, F. G.; LUND, R. G.; JUSTINO, L. M.; DEMARCO, F. F.; DEL PINO, F. A. B.; FERREIRA, R. Vinte e quatro meses de heterocontrole da fluoretação das águas de abastecimento público de Pelotas, Rio Grande do Sul, Brasil. Cadernos de Saúde $\begin{array}{lllllll}\text { Pública, } & \text { v. } & 20, & \text { n. } & 2, & \text { p. } & 422-429,\end{array}$ https://doi.org/10.1590/S0102-311X2004000200009

LINS-CANDEIRO, C. L. Monitoramento de fluoreto nas águas de abastecimento público: comparação entre a técnica eletrométrica e a colorimétrica. 2018. 26 f. Monografia (Graduação em Odontologia) - Universidade Federal de Uberlândia, Uberlândia, 2018.

MAIA, L. C.; VALENÇA, A. M. G.; SOARES, E. L.; CURY, J. A. Controle operacional da fluoretação da água de Niterói, Rio de Janeiro, Brasil. Cadernos de Saúde Pública, v. 19, n. 1, p. 61-67, 2003. https://doi.org/10.1590/s0102-311x2003000100007

MOIMAZ, S. A. S.; GARBIN, C. A. S; IGLESIAS, G. F.; CHIBA, F. Y.; SUMIDA, D. H.; SALIBA, O. Dificuldades enfrentadas no processo de fluoretação das águas de abastecimento público. Revista Brasileira de Pesquisa em Saúde, v. 17, n. 1, p. 87-94, 2015.

MOIMAZ, S. A. S.; SALIBA, O.; CHIBA, F. Y.; SUMIDA, D. H.; GARBIN, C. A. S.; SALIBA, N. A. Fluoride Concentration in Public Water Supply: 72 Months of Analysis. Brazilian Dental Journal, v. 23, n. 4, p. 451-456, 2012. https://doi.org/10.1590/S010364402012000400024 
MOTTER, J.; MOYSES, S. T.; FRANÇA, B. H. S.; CARVALHO, M. L.; MOYSÉS, S. J. Análise da concentração de flúor na água em Curitiba, Brasil: comparação entre técnicas. Revista Panamericana de Saúde Pública, v. 29, n. 2, p. 120-125, 2011. https://doi.org/10.1590/s1020-49892011000200007

NARVAI, P. C. Cárie dentária e flúor: uma relação do século XX. Ciência \& Saúde Coletiva, v. 5, n. 2, p. 381-392, 2000. https://doi.org/10.1590/S1413-81232000000200011

OLIVATI, F. N.; SOUZA, M. L. R.; TENUTA, L. M. A.; CURY, J. A. Quality of drinking water fluoridation of Capão Bonito, SP, Brazil, evaluated by operational and external controls. Revista Odonto Ciência v. 26, n. 4, p. 285-290, 2011. https://doi.org/10.1590/S1980-65232011000400002

PAREDES, S. O.; SAMPAIO, F. C.; FORTE, F. D. S. External Control over Fluoridation of the Public Water Supply in São Luís, MA, Brazil. Brazilian Research in Pediatric Dentistry and Integrated Clinic, v. 14, v. 2, p. 129-40, 2014. http://dx.doi.org/10.4034/PBOCI.2014.142.07

PETERSEN, P. E.; LENNON, M. A. Effective use of fluorides for the prevention of dental caries in the 21st century: the WHO approach. Community Dentistry and Oral Epidemiology, v. 32, n. 5, p. 319-321, 2004. https://doi.org/10.1111/j.16000528.2004.00175.x

PIORUNNECK, C. M. O.; DITTERICH, R. G.; GOMES, E. C. Heterocontrole da fluoretação nos municípios da região Metropolitana de Curitiba nos anos de 2014 e 2015. Cadernos Saúde Coletiva, v. 25 n. 4, p. 414-422, 2017. http://dx.doi.org/10.1590/1414462x201700040171

PRASAD, N.; PUSHPAANGAELI, B.; RAM, A.; MAIMANUKU, L. Fluoride concentration in drinking water samples in Fiji. Australian and New Zealand Journal of Public Health, v. 42, n. 4, p. 372-374, 2018. https://doi.org/10.1111/1753-6405.12787

RAMIRES, I.; BUZALAF, M. A. R. A fluoretação da água de abastecimento público e seus benefícios no controle da cárie dentária: cinquenta anos no Brasil. Ciência \& Saúde Coletiva v. 12, n. 4 , p. $1057-1065$, 2007. https://doi.org/10.1590/S141381232007000400027

UCHIDA, T. H.; CURY, J. A.; TABCHOURY, C. O. M.; TERADA, R. S. S.; FUJIMAKI, M. Heterocontrole da fluoretação da água de abastecimento público da $15^{\mathrm{a}}$ Regional de Saúde do Paraná. Revista de Saúde Pública. v. 1, n. 1, p. 59-67, 2018. https://doi.org/10.32811/2595-4482.2018v1n1.40

VON ELM, E.; ALTMAN, D. G.; EGGER, M.; POCOCK, S. J.; GOTZSCHE, P. C.; VANDERBROUCKE, J. P. The Strengthening the Reporting of Observational Studies in Epidemiology (STROBE) Statement: Guidelines for Reporting Observational Studies. Journal of Clinical Epidemiology, v. 61, n. 4, p. 344-349, 2008. https://doi.org/10.1016/j.jclinepi.2007.11.008

ZIMMER, S.; JAHN, K. R.; BARTHEL, C. R. Recommendations for the use of fluoride in caries prevention. Oral Health \& Preventive Dentistry. v. 1, n. 1, p. 45-51, 2003. 